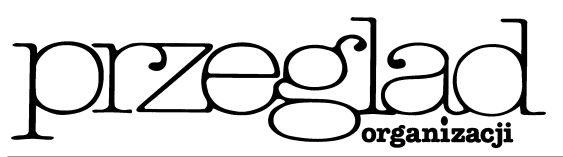

\title{
Kompetencje jako opcje strategiczne przedsiębiorstwa
}

https://doi.org/10.33141/po.2005.12.01

\section{Grzegorz Urbanek}

\section{Wprowadzenie}

$\mathbf{F}$ undamentalną podstawą długoterminowego powodzenia przedsiębiorstwa jest osiągnięcie i utrzymanie silnej pozycji rynkowej, której efektem jest trwała przewaga konkurencyjna. Uzyskanie wiedzy na temat źródeł przewagi, czyli zasobów i działań, które do niej prowadza, jest z tego punktu widzenia kluczem do sukcesu. Trwałą przewagę konkurencyjną można zdefiniować jako rozciągnięte w czasie korzyści będace wynikiem stosowania unikatowej, kreującej wartość strategii, która nie jest w tym samym czasie realizowana przez konkurentów, i której korzyści nie mogą być skopiowane ${ }^{11}$.

Każda firma może mieć przewagę nad innymi w szeregu czynników, ale najważniejsze przewagi dotyczą tych obszarów, które są cenione najbardziej przez klientów. Dlatego wysiłki firmy powinny być ukierunkowane w pierwszej kolejności na tworzenie wartości dla klienta w sposób dla niej dochodowy. Drogą do tego jest stosowanie unikatowej strategii, ponieważ każda inna będzie łatwa do skopiowania i nie będzie prowadziła do trwałych rezultatów. Celem artykułu jest prezentacja sposobu kreowania opcji strategicznych przedsiębiorstwa przez tworzenie i wykorzystanie unikatowych kompetencji.

\section{Klasyczne podejście pozycyjne i zasobowe do przewagi konkurencyjnej}

W

latach 70. i 80. ub. wieku, literatura dotycząca strategii koncentrowała się na zewnętrznym środowisku firmy. Stąd główny nacisk badawczy był położony na analizę atrakcyjności sektora i konkurentów. Obowiązującą teorią był wówczas model Portera, w którym poszukując źródeł przewagi konkurencyjnej koncentrowano się na zewnętrznym środowisku firmy, w szczególności strukturze sekto$\mathrm{ra}^{2}$. W zgodzie z teorią neoklasyczną ekonomii, zasoby były traktowane jako równomiernie rozłożone w sektorze i łatwo dostępne przez konkurujące firmy. W tej sytuacji rolą zarządzających było jak najlepsze zintegrowanie produktów i rynków w warunkach oddziaływania sił konkurencyjnych (siły przetargowej dostawców i odbiorców, barier wejścia, substytutów). W efekcie wysiłki zarządów kierowały się na zewnątrz firmy i były skoncentrowane na walce rynkowej3).

W końcu lat 80. zaczęły pojawiać się opinie podważające poprzednie poglądy. Nowy sposób spojrzenia na przewagę konkurencyjną został później nazwany podejściem „zasobowym”. Teoria zasobowa ma swoje źródła w poglądach Davida Ricardo, Josepha Schum-
Przegląd Organizacji, Nr 12 (791), 2005, ss. 7-10 www.przegladorganizacji.pl Towarzystwo Naukowe Organizacji i Kierownictwa (TNOiK) petera i Edith Penrose ${ }^{4)}$. Podejście oparte na zasobach traktuje firmę jako heterogeniczny podmiot, który charakteryzują jego unikatowa baza zasobów i różnorodne szczególne kompetencje. Ponieważ znaczna część tych zasobów i kompetencji nie zawsze może być przetransferowana lub skopiowana, szukając źródeł przewagi konkurencyjnej trzeba przyjąć perspektywę „do wewnątrz" i skoncentrować się na analizie wewnętrznych zasobów. Firmy mogą wpływać na poprawę osiąganych wyników poprzez rozwijanie swoich zasobów. Tak więc zgodnie z teoria zasobową firma może uzyskać ponadprzeciętne dochody tylko wtedy, gdy posiada lepsze od konkurentów zasoby i są one chronione przez jakąś formę mechanizmu izolacji, który zapobiega ich rozprzestrzenianiu w sektorze.

\section{Kapitał klienta i nowe podejście do przewagi konkurencyjnej}

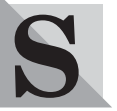

ilna pozycja rynkowa i przewaga konkurencyjna przedsiębiorstwa są rezultatem odpowiedniego zestrojenia i wykorzystania zasobów, będących w jego dyspozycji, do tworzenia kompetencji kreujących obecną i przyszłą wartość dla klienta, w sposób efektywniejszy niż robią to konkurenci. Głównym zadaniem dla zarządzających jest, obok najlepszej eksploatacji posiadanej pozycji rynkowej, sposób stworzenia unikatowej obecnej i przyszłej architektury zasobów, która będzie tworzywem kluczowych kompetencji. W tym celu należy określić, jakie zasoby przedsiębiorstwa są najważniejsze dla osiągnięcia sukcesu obecnie i w przyszłości, w jaki sposób należy je rozwijać i chronić, które zasoby można stosować na zasadzie outsourcingu, a które budować wspólnie z partnerami poprzez alianse i sieci.

W podejściu zasobowym punktem wyjścia do sformułowania strategii jest identyfikacja i analiza zasobów przedsiębiorstwa. Na podstawie wyników tej analizy formułowana jest strategia, która ma na celu najlepsze wykorzystanie posiadanych zasobów do generowania renty ekonomicznej, na bazie pojawiających się okazji rynkowych. Jest to podejście od wewnątrz na zewnątrz, które kładzie nacisk na odpowiednie ukształtowanie wewnętrznych zasobów przedsiębiorstwa.

W podejściu pozycyjnym punktem wyjścia do opracowania strategii jest analiza sektora pod kątem jego struktury. Dzięki znajomości struktury sektora (sił konkurencyjnych i grup strategicznych), firma może zmienić swoją strategię (pozycję w sektorze) w celu osiągnięcia lepszych niż konkurenci wyników. Jest to podejście od zewnątrz do wewnątrz, które kładzie nacisk na odpowiednie pozycjonowanie organizacji 
w swoim otoczeniu - w taki sposób, aby najlepiej „ustawić się" względem zewnętrznych okoliczności.

W zintegrowanym podejściu, jednocześnie „od wewnątrz na zewnątrz" i „od zewnątrz do wewnątrz”, źródłem przewagi konkurencyjnej jest odpowiednie powiązanie rozwoju wewnętrznych zasobów przedsiębiorstwa z zewnętrznymi czynnikami rynkowymi, tzw. determinantami kapitału klienta. Z punktu widzenia rynku, czynnikami budującymi kapitał klienta moga być: obiektywna wartość produktu - kapitał wartości, postrzeganie marki i jej image - kapitał marki, relacje z klientami - kapitał relacji ${ }^{5}$. Punktem wyjścia procesu formułowania strategii jest identyfikacja najważniejszych czynników budujących wartość dla klienta w branży, czyli tzw. rynkowych kluczowych czynników sukcesu obecnych i przyszłych. Określenia bieżących rynkowych czynników sukcesu można dokonać badając preferencje konsumentów. W przypadku przyszłych czynników sukcesu do tego celu można wykorzystać metody scenariuszowe.

Znając relatywne znaczenie czynników tworzących wartość dla klienta można określić kompetencje, które należy posiadać, aby efektywnie tę wartość tworzyć. Kluczowy czynnik sukcesu w branży może mieć swój odpowiednik w przedsiębiorstwie, tj. określoną kompetencję albo umiejętność. Przykładowo, odpowiednikiem kluczowego czynnika sukcesu - dostępności produktu jest kompetencja w zakresie efektywnej dystrybucji, odpowiednikiem prestiżu wizerunku jest kompetencja w zakresie tworzenia określonych skojarzeń itp. Porównanie kompetencji posiadanych przez firmę z wymogami rynkowymi i kompetencjami konkurentów pozwala na identyfikację ewentualnej luki kompetencyjnej, która powinna być zamknięta poprzez rozwój zasobów tworzących kompetencję. Trzeba jednak pamiętać, że próba dorównania konkurencji pod względem kompetencji może być zadaniem bardzo złożonym. Kluczowa kompetencja konkurenta $z$ definicji jest trudna do skopiowania lub pozyskania z rynku. Zamiast zatem koncentrować się na naśladownictwie źródeł przewagi konkurenta, firma powinna skoncentrować swoją strategię na eksploatacji tego, w czym jest najlepsza oraz tworzeniu nowych unikatowych kompetencji.

Spośród wszystkich kompetencji należy zidentyfikować te, które są kluczowe. Kompetencja jest kluczowa, jeżeli zwiększa postrzeganą wartość dla klienta, dostarczając mu istotnych korzyści. Rozróżnienie pomiędzy zwykłymi a kluczowymi kompetencjami opiera się na rozróżnieniu pomiędzy kluczowymi a zwykłymi korzyściami, jakie są udziałem klienta. Aby kompetencja była kluczowa, musi być dodatkowo unikatowa lub jej poziom musi znacząco przekraczać poziom kompetencji u konkurentów. Kluczowa kompetencja powinna mieć zastosowanie nie tylko w dzisiejszych, ale również w przyszłych działaniach firmy ${ }^{6}$. Wreszcie kluczowa kompetencja powinna być trudna do imitacji. Trudność w skopiowaniu kompetencji jest funkcją liczby, rodzaju i charakteru wzajemnych powiązań pomiędzy zasobami, aktywami i zdolnościami, które ją tworzą. Im więcej elementów ma udział w tworzeniu kompetencji, im bardziej mają one charakter niematerialny i im więcej powiązań występuje między nimi, tym trudniej jest powielić kompetencję.
Wartość kompetencji wzrasta, jeśli jest ona na tyle uniwersalna, że może być wykorzystana w różnych biznesach.

Prezentowany sposób budowy strategii jest w znacznym stopniu spójny ze zmodyfikowanymi, w stosunku do pierwotnych, poglądami Portera. Porter twierdzi, że poszukiwanie przewagi konkurencyjnej jest procesem od zewnątrz do wewnątrz i na odwrót. Trwała przewaga konkurencyjna ma źródła w zdolnościach firmy do dokonywania innowacji lepiej niż konkurenci w dłuższym okresie, ale w określonym momencie relatywna pozycja w stosunku do konkurentów jest najważniejsza. Pozycja ta jest zdefiniowana jednocześnie przez działania firmy i wymogi rynku, dlatego do zdobycia przewagi konkurencyjnej potrzebne są zasoby i jednocześnie odpowiednie pozycjonowanie ${ }^{7}$.

Analogicznie, w prezentowanym podejściu o przewadze konkurencyjnej przedsiębiorstwa w dłuższym okresie decyduje umiejętność tworzenia zasobów i opartych na nich kompetencji, które pozwolą firmie na najlepsze zaspokajanie przyszłych potrzeb klientów, zarówno tych, które pojawią się jako efekt trendów w otoczeniu, jak i wykreowanych przez firmę. W określonym momencie przewaga konkurencyjna jest wynikiem posiadania kompetencji, które są zgodne $\mathrm{z}$ wymogami rynku (determinantami kapitału klienta) i których poziom (pozycja) przewyższa poziom u konkurentów.

\section{Implikacje dla strategii}

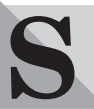

tosowana przez firmę strategia kształtuje jej wewnętrzne procesy, które ukierunkowują i koordynują zasoby pod kątem realizacji jej celów. Zasoby, które może wykorzystywać firma, leżą wewnątrz organizacji, albo poza nią - są wtedy własnością innych podmiotów lub dobrem wspólnym (np. internet).

Firma może dążyć do realizacji celów poprzez „podwójne działanie” - wykorzystanie (lewarowanie) posiadanych kompetencji albo budowanie nowych ${ }^{8)}$. Wykorzystywanie kompetencji ma miejsce, gdy firma stosuje i koordynuje zasoby w sposób nie wymagający zmian jakościowych, zarówno jeżeli chodzi o same zasoby, jak i sposób ich koordynowania i stosowania. Z budowaniem kompetencji mamy do czynienia w sytuacji zmian jakościowych w samych zasobach, jak i sposobach ich koordynowania i stosowania. Każda firma stosuje własny zestaw działań implementacji i budowania kompetencji do realizacji krótko- i długoterminowych celów. Powoduje to powstanie różnic pomiędzy firmami, jeżeli chodzi o rodzaj posiadanych i dostępnych zasobów oraz sposób ich stosowania ${ }^{9)}$.

Możemy wyróżnić sześć podstawowych sposobów wykorzystania kompetencji i zdolności firmy jako dźwigni. Sposoby te wpisują się koncepcyjnie w macierz strategii Ansoffa ${ }^{10)}$. Pierwszy - intensyfikacja poprzez ulepszenia, które powodują lepszą obsługę obecnych klientów. Drugi - rozszerzenie poprzez wykorzystanie kompetencji do wejścia na nowe rynki. Trzeci - powiększenie, kiedy kompetencje są rozszerzane na dostarczanie dodatkowych usług obecnym klientom. Czwarty - konwersja poprzez wykorzystanie kompetencji do dostarczania usług nowym klientom. 
Piąty - innowacje poprzez wykorzystanie kompetencji do tworzenia i dostarczania nowych produktów. Szósty - dywersyfikacja poprzez budowanie nowych kompetencji, które będą podstawą do tworzenia nowych usług i produktów ${ }^{11}$.

Wykorzystanie i budowa kompetencji dostarczaja dwóch źródeł tworzenia wartości dla przedsiębiorstwa. Są to: wartość bieżąca przepływów z obecnych operacji (wykorzystanie kompetencji) i wartość opcji realnej tworzenia nowych przepływów finansowych (z inwestycji w nowe kompetencje). Opcje realne firmy mogą być traktowane jako opcje strategiczne rozwoju, produkowania i sprzedawania produktów. Budowanie kompetencji jest procesem, w którym firma tworzy nowe opcje strategiczne, będące źródłem przepływów pieniężnych w przyszłości. Wykorzystanie bieżących kompetencji oznacza wykorzystanie bieżących opcji strategicznych do oferowania produktów, generujących bieżące przepływy gotówkowe. Częśś z tych przepływów może zostać przeznaczona na budowanie nowych kompetencji, które w rezultacie stworzą nowe opcje strategiczne i nowe przepływy pieniężne, które będą alokowane na budowę nowych kompetencji itd. $\mathrm{Z}$ tego punktu widzenia podstawa konkurowania jest budowanie i wykorzystanie kompetencji w celu tworzenia i stosowania strategicznych opcji (rysunek 1) ${ }^{12}$.

Intensyfikując wykorzystanie kompetencji poprzez ich nowe zastosowanie trzeba pamiętać o możliwych ograniczeniach tego procesu. Po pierwsze, dywersyfikacja na bazie kompetencji może zakończyć się niepowodzeniem, z uwagi na ich nietransferowalność na nowe obszary, nawet w obrębie jednego przedsiębiorstwa. Po drugie, na danym rynku w zależności od momentu wejścia, istotne dla powodzenia mogą być inne kompetencje. Zastosowanie kompetencji w nowych warunkach powinno być prowadzone małymi krokami - metodą prób i błędów.

W przypadku budowy kompetencji, firma przeznacza środki na pozyskanie jakościowo innych niż po-

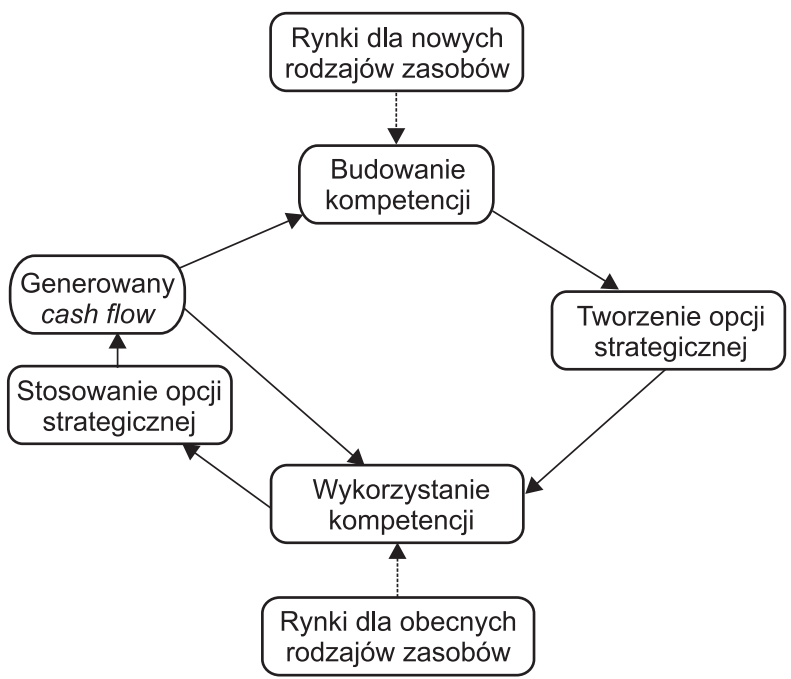

Rys. 1. Cykl budowy i wykorzystania kompetencji

Źródło: opracowano na podstawie: R. SANCHEZ, A. HEENE, Reinventing Strategic Management: New Theory and Practice for Competence-based Competition, „European Management Journal", vol. 5, nr 3, czerwiec 1997, s. 310. siadane, aktywów i zdolności. Może to być nowa technologia, nowi pracownicy, nowe procesy, procedury itp. Pozyskiwanie nowych zasobów może odbywać się poprzez ich rozwój wewnętrzny, albo poprzez zakup na zewnątrz. W procesie budowania i wykorzystywania kompetencji firma funkcjonuje jak otwarty system, który kooptuje i wykorzystuje zasoby różnego rodzaju z różnych źródeł.

Chociaż konkurencja odbywa się głównie na poziomie biznesu, trzeba pamiętać, że strategia na poziomie korporacji również konkuruje $\mathrm{z}$ innymi, $\mathrm{z}$ tym że rezultaty tej walki konkurencyjnej będą widoczne dopiero po wielu latach. Istotnym elementem strategii jest wybranie optymalnej struktury organizacyjnej, która będzie najlepiej odpowiadać jej realizacji zarówno na poziomie korporacji, jak i biznesu. Trzeba pamiętać, że przyszłe możliwości raczej nie będą idealnie mieścić się w ramach pojedynczego Strategic Business Unit (SBU) ${ }^{13)}$. Należy więc zdecydować, czy określona kompetencja będzie funkcjonowała w ramach SBU, czy będzie zarządzana ze szczebla korporacji i będzie „wynajmowana” SBU na zasadzie usłu$\mathrm{gi}^{14)}$. W sytuacji, gdy centrum zajmuje się dostarczaniem wyłacznie „standardowych" usług w postaci finansów, zarządzania personelem czy obsługi prawnej, natomiast nie zarządza kompetencjami, tworzona przez nie wartość dodana zwykle nie usprawiedliwia ponoszonych przez nie kosztów.

Rysunek 2 przedstawia kontekst tworzenia strategii budujacej i eksploatujacej kluczowe kompetencje, której celem jest uzyskanie przewagi konkurencyjnej i kreowanie wartości dla akcjonariuszy. Centralna część strategii stanowi identyfikacja zasobów i kompetencji, które mają decydujący udział w tworzeniu wartości dla klienta, a w konsekwencji dla akcjonariuszy. Analiza kompetencji firmy na tle konkurencji, a także obecnych i przyszłych determinantów kapitału klienta (rynkowych kluczowych czynników sukcesu) pozwala przedsiębiorstwu na opracowanie efektywnej strategii, która eksploatuje posiadane kompetencje, poprzez realizowanie bieżacych opcji strategicznych. Jednocześnie strategia prowadzi do alokacji środków na rozbudowę i tworzenie tych zasobów, które będą stanowić tworzywo przyszłych kluczowych kompetencji, a więc będą źródłem przyszłych opcji strategicznych.

Wartość dla akcjonariuszy przejawia się dwojako: w zależności od tego, czy jest efektem realizacji bieżących czy przyszłych opcji strategicznych przedsiębiorstwa. W przypadku realizacji bieżących opcji strategicznych firma generuje dochody (zysk, dodatnie przepływy gotówkowe), które znajdują odzwierciedlenie w sprawozdaniach finansowych lub krótkoterminowych projekcjach finansowych. Dochody te stanowia tę część wartości firmy, która jest liczona przy wykorzystaniu zdyskontowanych przepływów gotówkowych. W przypadku przyszłych opcji strategicznych w sprawozdaniach finansowych nie znajdujemy dodatkowych dochodów związanych z tymi opcjami, a wręcz przeciwnie. Stworzenie przyszłej opcji strategicznej wymaga inwestycji w budowę nowych kompetencji, opartych najczęściej na aktywach niematerialnych. Ponieważ wartość tych inwestycji odnoszona jest bezpośrednio w koszty i tym samym nie są one kapitali- 


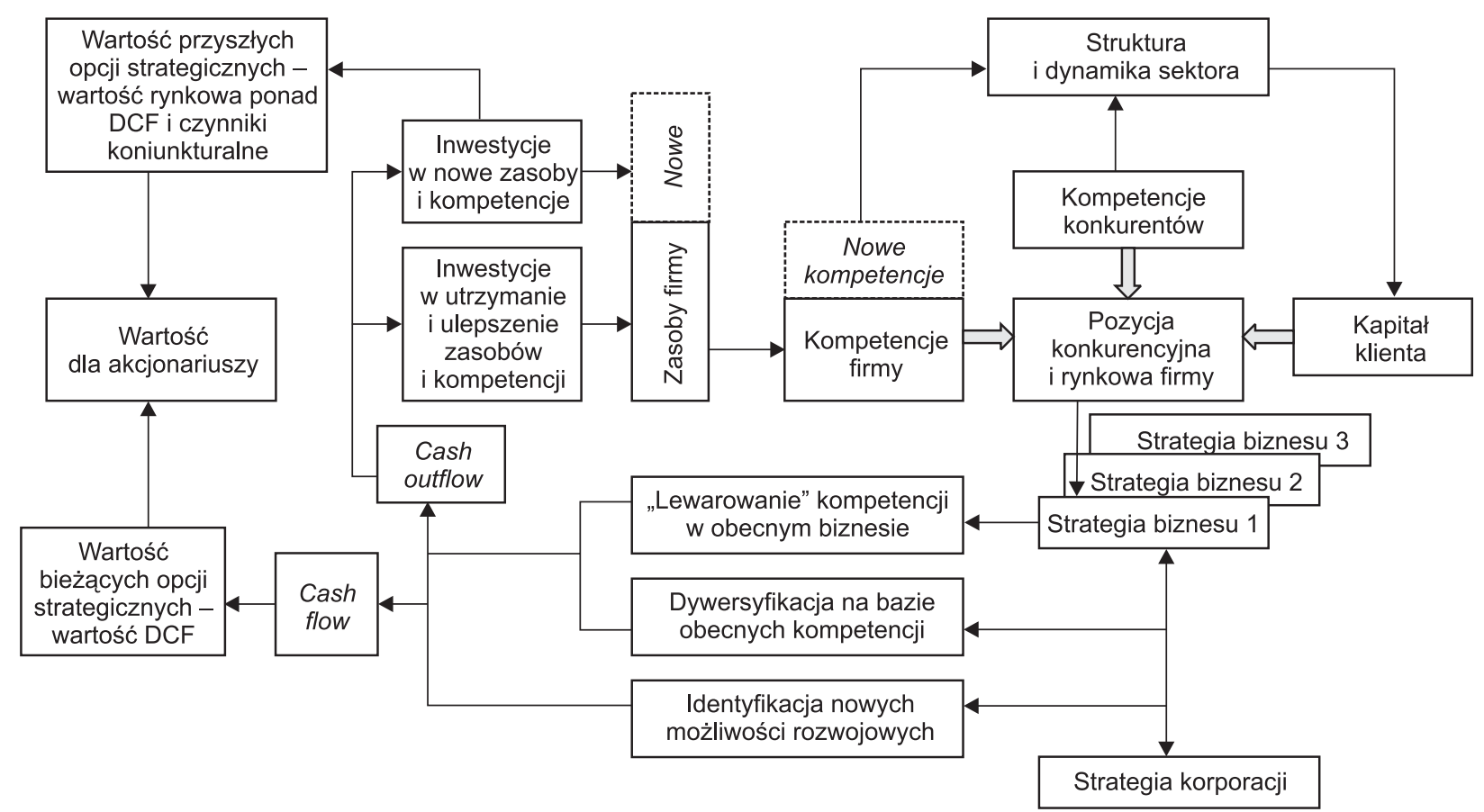

Rys. 2. Strategia jako proces budowy i wykorzystania kompetencji

Źródło: opracowanie własne.

zowane w bilansie, w związku z ich realizacją możemy spodziewać się spadku dochodów przedsiębiorstwa. Wartość przyszłych opcji strategicznych odkłada się w dwóch obszarach. Po pierwsze, w poziomie kompetencji firmy i jakości jej zasobów, których zmiany opisuja mierniki niefinansowe. Po drugie, dla firm notowanych na giełdzie, w tej części ich wartości rynkowej, której nie można objaśnić wielkością bieżących przepływów gotówkowych i zysków oraz czynnikami koniunkturalnymi. Według różnych źródeł, aż ok. 95\% zmian w cenach akcji nie można wyjaśnić informacjami finansowymi napływającymi ze spółek ${ }^{15)}$. Istotna część ceny akcji stanowi postrzeganie przez rynki finansowe wartości przyszłych opcji strategicznych przedsiębiorstwa, opartych na zasobach niematerialnych. Trzeba pamiętać, że niezależnie od tych ostatnich, czynnikami majacymi istotny wpływ na wycene giełdową firm są: koniunktura i psychologia rynków. Te niematerialne czynniki, będące poza kontrolą firmy, nie mogą być traktowane jako nośniki jej „fundamentalnej” wartości. Ich oddziaływanie wyjaśnia fluktuacje w wartości rynkowej przedsiębiorstw bez związku z ich bieżącymi wynikami finansowymi i poziomem zasobów niematerialnych (kompetencjami).

\section{Podsumowanie}

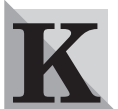
onkurencja jest to rywalizacja pomiędzy firmami zaangażowanymi w stosowanie i budowanie potrzebnych kompetencji, które umożliwiają im realizację celów. W tym ujęciu strategię można traktować jako proces transformacji wyobrażeń i poglądów menedżerów na temat kluczowych czynników sukcesu, na działania zmierzające do najlepszego rozwoju i wykorzystania organizacyjnych kompetencji, które determinują bieżącą i przyszłą pozycję firmy.
Efektem realizowanej strategii jest tworzenie zestawu dostępnych opcji, które zwiększają strategiczną elastyczność firmy, co umożliwia jej odpowiednią reakcję na pojawiające się możliwości i zagrożenia. dr Grzegorz Urbanek Katedra Zarzadzania Przedsiębiorstwem Uniwersytet Łódzki

\section{PRZYPISY}

1) J. BARNEY, Firm Resources and Sustained Competitive Advantage, „Journal of Management” 1991, 17(1), s. 99-120.

2) M.PORTER, Competitive Advantage, Free Press, New York 1985.

3) G. ROOS, J. ROOS, Measuring your Company's Intellectual Performance, „Long Range Planning” 1997, vol. 30, nr 3, s. 413-426.

4) R.M. GRANT, The Resourced-Based Theory of Competitive Advantage: Implications for Strategy Formula-tion, „California Management Review" 1991, wiosna, s. 114-135.

5) Zob. K. LEMON, V. ZEITHAM, R. RUST, Driving Customer Equity: How Customer Lifetime Value is Reshaping Corporate Strategy, Free Press 2000.

6) G. HAMEL, C.K. PRAHALAD, Competing for the Future, Harvard Business School Press, Boston 1994.

7) M. PORTER, What is Strategy?”, „Harvard Business Review”, (6) 1996 , s. $61-78$

8) D.F. ABELL, Managing with Dual Strategies: Mastering the Present, Preempting the Future, Free Press, Boston 1993.

9) R. SANCHEZ, A. HEENE, Reinventing Strategic Management: New Theory and Practice for Competence-based Competition, „European Management Journal”, vol. 5, nr 3, czerwiec 1997, s. 303-317.

10) I. ANSOFF, Corporate Strategy, Penguin, London 1987.

11) M. HAMMER, Beyond Engineering, Harper Collins, London 1996.

12) Zob. R. SANCHEZ, A. HEENE, op.cit., 1997.

13) G. HAMEL, C.K. PRAHALAD, op.cit., 1994.

14) Zob. R. KAPLAN, D. NORTON, The Balanced Scorecard, Harvard University Press, Massachusetts 1996.

15) Zob. np.: L. EDVINSSON, M. MALONE, Intellectual Capital, Harper Collins, London 1997 lub B. LEV, P. ZAROWIN, The Boundaries of Financial Reporting and How to Extend Them, referat na „First Annual Conference on Intangibles”, NYU, maj 1998. 